УДК 371.32.91(07)

DOI:

Святослав Юрченко, здобувач ступеня доктора філософiï, ДВНЗ “Прикарпатський національний університет імені Василя Стефаника”

\title{
ФОРМУВАННЯ ЕКОНОМІЧНИХ ЗНАНЬ І ПРОФЕСІЙНОЇ ОРІСНТАЦІЇ УЧНІВ 9-Х КЛАСІВ В ПРОЦЕСІ РОБОТИ З ПІДРУЧНИКОМ ГЕОГРАФІЇ (2009 - 2017)
}

У статті подано та розглянуто підручники з географії для 9-го класу в період з 2009 до 2017 р. на предмет формування в учнів економічних знань і вмінь, а також проаналізовано можливості підручників в аспекті економічного навчання й виховання. Розкрито шляхи та методи ефективної реалізації економічних знань в змісті підручника. Подано прийоми щчодо використання методичного апарату й ілюстративного матеріалу икільного підручника з географії щзоб досягнути певного рівня економічної компетентності як інтегрального показника когнітивної та дослідницької діяльності учнів. Показана роль шкільного підручника з географії для 9-го класу як умова професійної орієнтації учнів. Визначено місие економічних знань у змісті икільної географічної освіти.

Ключові слова: підручник; географія; економічні знання та освіта; професійна орієнтація; аналіз змісту; методи; форми; технологіі.

תim. 9.

Sviatoslav Yurchenko, Applicant of the degree of Doctor of Philosophy SHEI "Vasyl Stefanyk Precarpathian National University"

\section{FORMATION OF ECONOMIC KNOWLEDGE AND VOCATIONAL ORIENTATION OF THE 9TH GRADERS IN THE COURSE OF WORK WITH THE TEXTBOOK OF GEOGRAPHY (2009-2017)}

The article presents and reviews geography textbooks for the 9th grade for the formation of pupils' economic knowledge and skills, as well as analyzes the possibilities of textbooks in the aspect of economic education and upbringing. The ways and methods of effective realization of economic knowledge in the content of the textbook are revealed. Techniques for using the teaching apparatus and illustrative material are presented, and methodological recommendations for the use of materials of geography textbooks for the 9th grade for the purpose of achieving economic competence as an integral indicator of cognitive and research activity of students are determined. The role of school textbook on geography for the 9 th grade as a condition of students' professional orientation is shown. The place of economic knowledge in the content of school geographical education is determined.

The lack of thorough research on the formation of economic knowledge and guidance of pupils in the course of working with a textbook on geography for the ninth grade for secondary schools is the relevance of this study.

The purpose of this study is to analyze school textbooks on geography for 9th grade during 2009-2017 in order to study formation of pupils' economic knowledge and substantiation of the need for economic education of pupils, as a condition of professional orientation of pupils. The study compares two textbooks on geography for the 9th grade, textual and illustrative textbooks for the formation of pupils of economic knowledge and vocational guidance in the work of pupils with the textbook. It has been researched that the textbook is one of the most important tools for acquiring and learning pupils knowledge.

Keywords: a textbook; geography; economic knowledge and education; vocational guidance; content analysis; methods; forms; technologies.

П остановка проблеми. У шкільному курсі економічна географія разом 3 іншими освітніми дисциплінами покликана готувати учнів до активної життєдіяльності. Одне з основних його завдань здійснення економічної освіти школярів, яка передбачає розвиток мислення школярів, зокрема дев'ятикласників через засвоєння ними економічних понять, закладених у програмний матеріал, встановлення причинново-наслідкових зв'язків, вироблення вмінь і навичок роботи зі статистичними матеріалами. Озброєний знаннями молодий будівник суспільства в різних ситуаціях повинен обстоювати свій погляд економного господаря.

У процесі студіювання означеного напряму, зокрема під час вивчення основних галузей народного господарства країни, окремих областей, економічних районів своєї області і свого міста, учні дістають інформацію про професії. Підвищенню ефективності економічного виховання, правильному вибору професії сприяе використання вчителем різноманітних методів навчання: розповідь, бесіда, індивідуальні заняття, 


\section{ФОРМУВАННЯ ЕКОНОМІЧНИХ ЗНАНЬ І ПРОФЕСІЙНОЇ ОРІЄНТАЦІЇ УЧНІВ 9-Х КЛАСІВ}

В ПРОЦЕСІ РОБОТИ 3 ПІДРУЧНИКОМ ГЕОГРАФІЇ (2009 - 2017)

зустрічі з людьми різних професій, екскурсії на виробництво, широке застосування наочності (економічні схеми, таблиці, малюнки, натуральні колекції промислової та сільськогосподарської сировини та ін.).

У сучасних умовах в економіці нашої країни спостерігаються негативні явища в розвитку господарства та економічних районів. Тому корінної перебудови потребують методи управління економікою, що має бути досягнуто в результаті кардинальної економічної реформи. У зв'язку з цим зростає роль шкільного курсу економічної і соціальної географії України, що покликаний формувати в учнів - завтрашніх працівників різних сфер народного господарства - сучасне економіко-географічне, економічне та екологічне мислення для розв'язання найважливіших народногосподарських проблем. Майбутні працівники народного господарства мають мислити категоріями прискорення, перебудови, підвищення ефективності виробництва і якості продукції, бережливого ставлення до природи і природних ресурсів [9, 22]. Перебудова сучасних українських закладів середньої освіти має передбачати зміни в змісті, структурі та методах навчання. При цьому ключові завдання сучасного етапу підвищення продуктивності діяльності на основі інтенсифікації виробництва, поєднання переваг по досягненню науковотехнічного прогресу поширюються і на сферу освіти. Мова йде насамперед про зростання якості освітнього процесу школи та його ефективності. Звичайно, усе це стосується і шкільного підручника з географії для 9-го класу як одного з безпосередніх засобів отримання та засвоєння учнями знань однак відсутність грунтовних досліджень на предмет формування економічних знань та профорієнтації школярів у процесі роботи з підручником на уроках географії для 9-го класу для ЗСО зумовлює актуальність пропонованої розвідки.

Аналіз основних досліджень і публікацій. Проблемі підручникотворення у системі шкільної географічної освіти знайшла висвітлення у низці наукових розвідок. Серед основоположних теорій функціонування та дослідження теорії підручника можна виділити праці вітчизняних вчених. Так, за Г. Ващенком, виокремлюють такі вимоги до підручникотворення для 3СО:

1) за своїм змістом він мусить стояти на рівні сучасної науки навіть тоді, коли призначений для дітей молодшого віку. Малій дитині школа не може давати відомостей, що не відповідають науковій правді, бо це викривлювало б дитячий світогляд;

2) як зміст, так і форма підручника мають відповідати віковим особливостям дитини і бути для неї зрозумілими, принаймні, після пояснень учителя;

3) виклад його мусить бути систематичним i послідовним не тільки 3 погляду логічного, а й психолого-педагогічного, себто в ньому мусить бути поступовий перехід від відомого до невідомого, від простого до складного, від близького до далекого;

4) підручник має збуджувати інтерес до знання, стимулювати самостійні шукання учнів;

5) мова підручника мусить бути точна, проста $\mathrm{i}$ водночас жива. Писати так дуже важке завдання. Тимто книги для дітей часто бувають або сухі й нудні, або роблено наївні, що теж небажано;

6) крім освітніх завдань, книга має виконувати й завдання виховні [1, 215-216].

Суттєву увагу розробці теорії підручника приділялиусвоїх фундаментальнихпрацяхВ.Беспалько, I. Лернер, В. Максаковський, В. Онищук, О. Савченко, М. Скаткін, В. Сухомлинський та ін. Останні публікації, що стосуються проблематики підручникотворення в галузі географічної освіти в Україні, окреслені в роботах Т. Мартинюк, С. Коберніка, В. Надтоки, О. Надтоки, Т. Назаренко, Л. Покась, О. Топузова. Одним із перших питання про необхідність опанування економічних знань у процесі навчання географії було поставлено М. Баранським і надалі розвинуто у працях А. Даринського, М.Ковалевської,М.М.Панчешникової та інших учених-методистів.

У 60-х рр. ХІХ ст., усвідомлюючи вимоги часу, К. Ушинський сформулював завдання підготовки підростаючого покоління до економічного життя суспільства. У своїй праці “Про камеральну освіту він писав”: “... Нашому століттю давно вже дорікають в індустріальному напрямі, давно вже встигли довести й безглуздість цих докорів. Але представником цього напряму в світі науки має бути наука про господарство. Зміна в напрямі століття потребує, щоб і навчання молоді змінило свою спрямованість..." [8, 121-253].

Економічне виховання А. Макаренко називав господарчим. Автор підкреслював, що в житті держави кожна людина протягом свого життя неодмінно братиме участь. Людина 3 великим багажем знань принесе користь державі та самій собі. Господарче виховання дитини однак не тільки господаря в сім’і, але й у суспільстві. Антон Семенович акцентував увагу на тому, що економічне та трудове виховання - це міцний симбіоз, який дає можливість для формування поваги до праці та прояву низку особистих якостей, зокпема: діловитості, бережливості та вміння застосувати їх у реальному житті [4, 214-230]. 


\section{ФОРМУВАННЯ ЕКОНОМІЧНИХЗНАНЫ І ПРОФЕСІЙНОӤ ОРІЕНТАЦІЇ УЧНІВ 9-Х КЛАСІВ В ПРОЦЕСІ РОБОТИ 3 ПЦДРУЧНИКОМ ГЕОГРАФІЇ (2009-2017)}

За О. Співаковським “... саме шкільному курсу географії необхідно відвести чільне місце для підготовки нового покоління до змін у способах життєдіяльності людської цивілізації' [7, 228].

Різноманітні аспекти, пов'язані з питаннями удосконалення шкільних підручників, висвітлені в працях вітчизняних та зарубіжних дослідників. Зокрема, філософію і теорію підручникотворення розглядали Р. Арцишевський, В. Бейлінсон, Л. Березівська, В. Беспалько, С. Бондаренко, Г. Гранік, І.Журавлев, Д.Зуєв, Ю. Кузнєцов, І. Лернер, Н. Тализіна, А. Хуторськой, С. Ямшиніна; стратегія створення українського підручника є об'єктом наукового дослідження О. Савченко, С. Гончаренка, Н. Бібік, М. Бурди, Н. Буринської, О. Ляшенка, Ю. Завалевського. Методичні засади роботи з підручником вивчалася М. Головко, М. Фіцулою, В. Власовим. Предметом спеціальних досліджень стали: підручник як засіб формування ключових і предметних компетентностей учнів (I. Гузик, Л. Гавриленко, В. Мелешко, Л. Махмутова); питаннями розробки концепції електронного підручника займалися В. Биков, В. Волинський, С. Волков, Ю. Іванов, М. Лось, І. Підласий, T. Соколовська, Т. Романченко. Актуальні проблеми вдосконалення підручників аналізували і психологи-науковці. Розроблялися психологічні принципи і вимоги до підручника, запропонована психологічна концепція типологізації та відбору навчального матеріалу (В. Андрієвська, Г. Балл, Г. Костюк, Н. Менчинська).

Над проблемою професійної орієнтації учнівської молоді працювали і працюють багато дослідників. Так, психолого-педагогічним та соціально-економічним основам підготовки молоді до вибору професії присвятили праці К. Бондарчук, В. Гладкова, М. Захаров, Л. Калініна, В. Кизенко, С. Клімов, О. Корсакова, Е. Лібанова, Ю. Маршавін, І. Назімов, М. Піддячий, Г. Покиданов, К. Платонов, М. Пряжніков, В. Пухлій, В. Рижков, В. Савченко, В. Симоненко, С. Чистякова, Б. Федоришин, В. Ядов та інші.

Метою статті $\epsilon$ аналіз шкільних підручників 3 географії для 9-го класу протягом 2009-2017 років на предмет формування у школярів економічних знань та обгрунтування необхідності їх економічної освіченості, як умови професійної орієнтації.

Для досягнення зазначеної мети поставлено такі завдання: проаналізувати змістове наповнення шкільних підручників з географії для 9-го класу зазначеного періоду в контексті формування в учнів економічних знань, виявити можливості підручників 3 географії для 9-го класу в забезпеченні економічної освіти і виховання учнів, з'ясувати відповідність використання підручників на предмет профорієнтації у процесі економічного навчання й виховання учнів на уроках географії в 9-му класі.

Для розв'язання поставлених завдань використано теоретичні методи - аналіз педагогічної й навчально-методичної літератури, синтез і узагальнення теоретичних положень для обгрунтування педагогічних умов формування економічних знань учнів 9-х класів у процесі вивчення географії через зміст підручника; інтеграційний метод-порівняння; герменевтичний - для аналізу ідей авторів підручників.

Виклад основного матеріалу. Економічні та економіко-географічні знання, що їх учні здобувають в курсах економічної географії України і які сприяють розвитку економічного мислення школярів, можна об'єднати у такі групи:

1. Суто економічні знання: це знання про народне господарство, його структуру, сфери, галузі, типи підприємств, форми організації виробництва, формування понять “продуктивність праці”, “собівартість продукції” Аналізуючи підручник з географії як безпосередній засіб навчання та засвоєння отриманої інформації, на прикладі підручника В. Пестушка і Г./ Уварової для 9-го класу, бачимо, що в темі “Загальна характеристика господарства України” [5, 54] найбільше висвітлена вищеподана інформація.

Для закріплення теоретичного матеріалу учні аналізують особливості розміщення виробництва, роблять найпростіші розрахунки за статистичними даними, вчаться працювати 3 картами. Вони ознайомлюються 3 техніко-економічними показниками підприємств і новими технологіями виробництв, дізнаються про те, як ефективно використовувати виробничий і науково-технічний потенціал в умовах інтенсифікації економіки країни. Саме для закріплення отриманого матеріалу в підручнику географії для 9-го класу, авторами якого є Т. Гільберг, І. Савчук та В. Совенка в темі “Національна економіка" [2, 10], текстова інформація подана так, що теоретичний матеріал одразу подається в конкретних прикладах: національна економіка в контексті світової економіки, форми суспільної організації виробництва тощо. Матеріали даного підручника, а саме параграф 24 “Кольорова металургія" [2, 130], дає можливість розкрити учням особливості технології виробництва в кольоровій металургії. Так, відомо, що для кольорових металів характерний незначний вміст металу в руді. Тому перший етап у технології кольорової металургїзбагачення руд і виробництво концентратів. Потім їх рафінують, тобто очищують від домішок (сірки) 
або інших металів. Вчитель зосереджує увагу на комплексному використанні сировини.

Під час вивчення теми “Машинобудування” в учнів насамперед формуються поняття “собівартість”, “спеціалізація”, “концентрація”, “кооперування”. А для того, щоб учні їх краще засвоїли навчальний матеріал, в підручниках поділено на різні види види практичних завдань на побудову схем, заповнення таблиць тощо. Адже самостійні та практичні роботи сприяють більш глибокому і свідомому формуванню в учнів економічних знань. Наприклад, у підручнику В. Пестушка і Г./ Уварової при вивченні теми “Електроенергетика" за Додатком 11 підручника [5, 261], пропонується побудувати секторну діаграму виробництва електроенергії ТЕС, АЕС і ГЕС. Користуючись таким планом, учні працюють не тільки зі статистичними таблицями додатка, а й з текстом підручника, картами атласу. Синтезуючи весь наявний матеріал, вони виконують поставлені завдання. Такі самостійні та практичні роботи сприяють активізації розумової діяльності на уроці, кращому і більш стійкому закріпленню навчального матеріалу.

2. Знання про трудові ресурси: кількість населення, його професійний склад, розподіл трудових ресурсів між виробничою i невиробничою сферою народного господарства, соціально-професійна і демографічна структура населення, форми, темпи і ривень урбанізації, шляхи раціонального використання трудових ресурсів тощо. Отримання цих знань учнями повною мірою забезпечує матеріал вміщений в підручнику В. Пестушка і Г./ Уварової, в якому виділена окрема тема “Трудові ресурси і зайнятість населення" [5, 48], на відміну від підручника Т. Гільберг, І. Савчук та В. Совенка, де ця тема не розглядається.

3. Знання про види природних ресурсів, про їх господарське та раціональне використання. Вони тісно пов'язані з розумінням взаємодії природних компонентів і необхідності бережливого ставлення до багатств природи. Учні вчаться давати господарську (економічну) оцінку, тобто встановлювати можливість і доцільність залучення природних ресурсів у виробництво при сучасному розвитку науки і техніки. Ці знання обгрунтовані в окремому розділі підручника 3 географії для 9-го классу Т. Гільберг, І. Савчук та В. Совенка “Глобальні проблеми людства" [2, 264]. Ознайомлюючись 3 використанням природних ресурсів у нашій країні, учні не тільки здобувають наукові знання, а й вчаться відповідально ставитися до збереження багатств природи та їх ощадливого використання, стають безпосередніми учасниками охорони рослинності та тваринного світу, джерел, земельних угідь тощо.

4. Економіко-географічнізнання про територіальну організацію виробництва, що включають розуміння понять “промисловий пункт”, “вузол”, “територіально-виробничий комплекс", “економічний район”, “міжнародний географічний поділ праці” тощо. Ця інформація достатньою мірою представлена в підручнику з географії для 9-го класу В. Пестушка і Г./ Уварової, в темі “Загальна характеристика господарства України" $[5,54]$.

Шкільний підручник з географії для дев'ятого класу також має великі можливості ознайомити учнів $з$ особливостями різних професій. Так, вивчаючи сільське господарство як складову частину агропромислового комплексу країни, дев'ятикласники ознайомлюються 3 деякими сільськогосподарськими професіями. Ця тема важлива для шкіл сільської місцевості, адже в умовах науково-технічного прогресу для роботи на селі необхідні кваліфіковані трактористи, комбайнери, оператори нової техніки.

На нашу думку, найбільші можливості для економічного навчання та професійної орієнтації учнів дає вивчення галузей господарства, особливостей виробничого процесу, типових підприємств. Під час вивчення основних галузей господарства України, окремих економічних районів, областей й міст, учні отримують розширену інформацію про різноманітні професії.

Висновки. Одним із ключових аспектів сучасної загальної освіти є розвиток творчих здібностей та формування професійного мислення, що допомагає розв'язувати будь-які життєві проблеми. Тому вивчення курсу шкільної географії має неабияке значення для розв'язання різноманітних соціальних завдань, адже це єдина шкільна навчальна дисципліна, яка пов'язує природничі та соціально-економічні знання 3 подальшим формуванням у тих хто навчається, світоглядного уявлення про рідну країну та світ. Цьому сприяють дидактичні методи й практичні викладання та відповідні наповнення змісту навчального курсу [3, 8].

При порівнянні двох підручників з географії для дев'ятого класу (В. Пестушко та Т. Гільберг) вдалося загалом підтвердити те, що підручник $\epsilon$ одним із найважливіших засобів для отримання та засвоєння знань учнями. Весь навчальний матеріал підручників з географії для 9-го класу, які були проаналізовані, дають змогу конкретизувати вислів: "Економіка повинна бути економною”. Навіть найменша економія 


\section{ФОРМУВАННЯ ЕКОНОМІЧНИХЗНАНЬ І ПРОФЕСІЙНОЇ ОРІЄНТАЦЇ̈ УЧНІВ 9-Х КЛАСІВ В ПРОЦЕСІ РОБОТИ З ПІДРУЧНИКОМ ГЕОГРАФІЇ (2009 - 2017)}

допоможе підвищити продуктивність праці. Так, економія $1 \%$ електроенергії в масштабах країни за рік дорівнює 13 мл кіловат-годин, а це продуктивність кількох потужних електростанцій, де спалюється 4,4 млн тонн палива. Щоб перевезти таку кількість палива, потрібно 73 тис. залізничних вагонів. Як бачимо, в процесі викладання географії в 9-му класі підручник має всі можливості, щоб правильно зорієнтувати старшокласників на вибір майбутньої професії. Подібні систематичні порівняння підручників, зокрема з географії для 9-го класу, в контексті формування економічної освіти учнів та їхньої професійної орієнтації не проводилися.

Таким чином, модернізація сучасної географічної науки у шкільному курсі базується на особистісних орієнтирах, де важливе місце належить формуванню компетентностей школярів. У цьому контексті географічна компетентність складається 3 інформації, яка містить компонент географії, формує світоглядну позицію учнів, складовими якої є оволодіння знаннями (когнітивний компонент), досвід прояву практичних навиків у діяльності та педагогічних ситуаціях (діяльнісний), відношення до безпосередньої діяльності та їі результатів (ціннісно-змістовий), емоційна та вольова регуляція/саморегуляція процесу та результату роботи, готовність до власного прояву у виконанні додаткових доручень $[6,16]$.

\section{ЛІТЕРАТУРА}

1. Ващенко Г. Загальні методи навчання: підручник для педагогів. Київ: Укр. видав. спілка, 1997. 415 с.

2. Гільберг Т., Савчук I., Совенко В. Географія: підручник для 9 кл. загальноосвіт. навч. закл. Київ: Оріон, 2017.288 c.

3. Жемеров О. Робота 3 підручником географії у загальноосвітній школі: метод. посіб. URL: http:// dspace.univer.kharkov.ua /bitstream/123456789/3632/2/ $\% \mathrm{D} 0 \% 9 \mathrm{~A} \% \mathrm{D} 0 \% \mathrm{~B} 0 \% \mathrm{D} 1 \% 80 \% \mathrm{D} 0 \% \mathrm{BF} \% \mathrm{D} 0 \% \mathrm{~B} 5 \% \mathrm{D} 0 \% \mathrm{~B}$ D\%D0\%BA\%D0\%BE.pdf (дата звернення: 25.03.2021).

4. Макаренко А. Деякі висновки з мого педагогічного досвіду. Твори в семи томах. Київ, 1954. Т. 5

5. Пестушко В, Уварова Г. Географія: підручник для 9 кл. загальноосвіт. навч. закл. Київ: Генеза, 2009. 288 с.

6. Самойленко В., Топузов О., Вішнікіна Л., Діброва I. Дидактика географії: монографія. Київ: Ніка-Центр, $2013.570 \mathrm{c}$

7. Співаковський О. Майбутнє шкільної інформатики. Тенденції розвитку освітніх інформаційнокомунікативних технологій. Науковий часопис НПУ імені М. П. Драгоманова: зб. наук. пращьь. Київ, 2005. №3 (10). C. 226-234.

8. Ушинский К. О камеральном образовании. Збірник творів в 11 томах. Москва: Акад. пед. наук РСФСР, 1948. Т. 8

9. Шпак О, Булавенко С, Примаченко Н. Профорієнтаційна робота в закладах загальної середньої освіти як основа соціалізації школярів. Молодь $і$ ринок. Щомісячний науково-педагогічний журнал. Дрогобич, 2019. №11 (178). С. 21-26.

\section{REFRERENCES}

1. Vashchenko, H. (1997). Zahalni metody navchannia. Pidruchnyk dlia pedahohiv [General teaching methods: a textbook for teachers]. Kyiv, 415 p. [in Ukrainian].

2. Hilberh, T. (2017). Heohrafiia : pidruchnyk dlia $9 \mathrm{kl}$. zahalnoosvit. navch. zakl. [Geography: a textbook for 9th grade secondary schools]. Kyiv, 288 p. [in Ukrainian]

3. Zhemerov, O. Robota z pidruchnykom heohrafii u zahalnoosvitnii shkoli: metodychnyi posibnyk. [Work with a textbook of geography in secondary school: a metod manual]. Available at: http://dspace.univer.kharkov.ua / b i t s t r e a m/123456789/3632/2/ $\% \mathrm{D} 0 \% 9 \mathrm{~A} \% \mathrm{D} 0 \% \mathrm{~B} 0 \% \mathrm{D} 1 \% 80 \% \mathrm{D} 0 \% \mathrm{BF} \% \mathrm{D} 0 \% \mathrm{~B} 5 \% \mathrm{D} 0 \% \mathrm{~B}$ D\%D0\%BA\%D0\%BE.pdf (Accessed 25 Mar. 2021). [in Ukrainian].

4. Makarenko, A. (1954). Deiaki vysnovky z moho pedahohichnoho dosvidu. [Some conclusions from my pedagogical experience]. Collected works in 7 vols. Kyiv, vol. 5, pp. 214-230. [in Ukrainian].

5. Pestushko, V. (2009). Heohrafiia : pidruchnyk dlia 9 kl. zahalnoosvit. navch. zakl. [Geography: a textbook for 9th grade secondary schools]. Kyiv, 288 p. [in Ukrainian].

6. Samoilenko, V., Topuzov, O., Vishnikina, L. \& Dibrova, I. (2013). Dydaktyka heohrafii [Didactics of geography]. Kyiv, 570 p. [in Ukrainian].

7. Spivakovskyi, O. (2005). Maibutnie shkilnoi informatyky. Tendentsii rozvytku osvitnikh informatsiinokomunikatyvnykh tekhnolohii [The future of school computer science. Trends in the development of educational information and communication technologies]. Scientific journal of NPU named after M. Drahomanov: collectionof scientific works. Kyiv, Vol. 3(10), pp. 226-234. [in Ukrainian].

8. Ushynskyi, K. (1948). O kameralnom obrazovanyy. [About cameral Education]. Collected works in 11 vols. Moscow, Leningrad, Academy of Pedagogical Sciences of RSFSR Publ., vol. 8, pp. 121-253. [in Russian].

9. Shpak, O., Bulavenko, S. \& Prymachenko, N. (2019). Proforiientatsiina robota $\mathrm{v}$ zakladakh zahalnoi serednoi osvity yak osnova sotsializatsii shkoliariv [Career guidance work in general secondary education institutions as a basis for socialization of schoolchildren]. "Youth and market". Monthly scientific-pedagogical journal. Drohobych, Vol. 11 (178), pp. 21-26. [in Ukrainian].

Стаття надійшла до редакції 22.02.2021

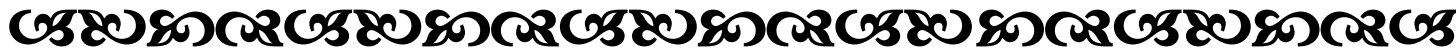

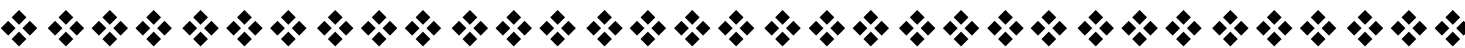

